\title{
Correction to: Metagenomic approaches: effective tools for monitoring the structure and functionality of microbiomes in anaerobic digestion systems
}

\author{
Annerys Carabeo-Pérez ${ }^{1} \cdot$ Gilda Guerra-Rivera $^{2} \cdot$ Miguel Ramos-Leal $^{3} \cdot$ Janet Jiménez-Hernández $^{1}$ \\ Published online: 9 November 2019 \\ (C) Springer-Verlag GmbH Germany, part of Springer Nature 2019
}

\section{Correction to: Applied Microbiology and Biotechnology} https://doi.org/10.1007/s00253-019-10052-5

The original version of this article was revised: After publication of this article, the publisher was notified that Michael Klocke was removed from the authors list. Based on his own wish and in agreement with all co-author the full list of authors has now been updated as follows:

Annerys Carabeo-Pérez, Gilda Guerra-Rivera, Miguel Ramos-Leal, Janet Jiménez-Hernández

The original article has been corrected.

Publisher's note Springer Nature remains neutral with regard to jurisdictional claims in published maps and institutional affiliations.

The online version of the original article can be found at https://doi.org/ $10.1007 / \mathrm{s} 00253-019-10052-5$

Janet Jiménez-Hernández

janet@uniss.edu.cu

1 Centro de Estudios de Energía y Procesos Industriales, Universidad de Sancti Spíritus “José Martí Pérez”, Ave de los Mártires No. 360, 60100 Sancti Spíritus, CP, Cuba

2 Facultad de Biología, Universidad de La Habana, Calle 25 e/ I y J, Vedado, 10400 Havana, CP, Cuba

3 Instituto de Investigaciones de Fruticultura Tropical, Ave. $7 \mathrm{ma}$ No. 3005, et. 30 y 32, Playa, 11300 Havana, CP, Cuba 